\title{
Hybrid Production Regimes and Labor Agency in Transnational Private Governance
}

\author{
Jean-Christophe Graz · Nicole Helmerich · Cécile Prébandier \\ Journal of Business Ethics \\ https://doi.org/10.1007/s10551-019-04172-1
}

Received: 9 October 2017 / Accepted: 29 April 2019 / published online: 9 May 2019

- Postprint version —

\begin{abstract}
$\underline{\text { Abstract }}$
Little consensus exists about the effectiveness of transnational private governance in domains such as labor, the environment, or human rights. The paper builds on recent scholarship on labor standards to emphasize the role of labor agency in transnational private governance. It argues that the relationship between transnational private regulatory initiatives and labor agency depends on three competences: first, the ability of workers' organizations to gain access to processes of employment regulation, implementation, and monitoring; second, their ability to insist on the inclusion of employers and state agencies within such processes; and third, the ability of workers to effectively exercise leverage in pursuit of particular goals. The paper develops a framework, called hybrid production regime, for examining how workers' capacity to act at the local level depends on how these three collective competences are addressed in the institutionalization of capital-labor relations between the transnational and national levels.
\end{abstract}

\section{Keywords}

Agency $\cdot$ Corporate social responsibility $\cdot$ Hybrid production regime $\cdot$ International political economy $\cdot$ Labor standards · Multi-stakeholder initiatives · Power $\cdot$ Transnational private governance

\section{Introduction $^{1}$}

The globalization of production networks over the last two decades has created new job opportunities in developing countries and emerging markets, but jobs in such countries are often characterized by low wages and poor working conditions. Major international organizations have emphasized the importance of collective industrial relations for achieving

\footnotetext{
${ }^{1}$ Acknowledgements: This article is part of a larger project on Transnational Private Regulation, Production Regimes and Power Resources, funded by the Swiss National Science Foundation. We thank the guest editors and the anonymous reviewers for their careful reading, insightful comments and suggestions. We also thank our colleagues for their comments at the Regulatory Governance Biennial Conference (Lausanne, July 2018) and at the conference of the European Association of Evolutionary Political Economy (Nice, September 2018). We also thank Tobias Berger, Conor Cradden, Alejandro Esguerra, Benjamin Faude, Lea Hartung, Anne Koch, Alexandros Tokhi for helpful suggestions. And special thanks to Liesl Graz for her invaluable help with the language.

Funding: This study was funded by the Swiss National Science Foundation - Grant \# 100017_162647.
} 
higher standards (Bakvis and McCoy 2008; Rodgers et al. 2009); this in turn has generated a broad and diverse range of studies on the challenges of promoting decent work and improved labor standards throughout global production networks (Barrientos, Mayer, et al. 2011; Lee and McCann 2011; Locke et al. 2013). While the transnational private governance of labor based on corporate codes of conduct and multi-stakeholders initiatives is seen to have some potential to improve employee welfare, little consensus exists on its effectiveness (Anner 2012a; Barrientos and Smith 2007; Fransen 2013; Locke et al. 2013; Robinson 2010). Current literature discusses the labor impact of a wide variety of standards, enforcement strategies and monitoring systems. It widely recognized that significant and permanent improvements in employee welfare are unlikely without the direct involvement of workers (Amengual and Chirot 2016; Egels-Zandén and Hyllman 2007; O’Brien 2013; Wells 2009). Yet few studies focus on the actual or potential relationship between transnational private labor governance and the emergence and development of independent worker organization and collective bargaining. More particularly, the exercise of labor rights is generally viewed as sensitive to local political and socio-cultural factors (Bair 2017; Carswell and De Neve 2013; Coe and Jordhus-Lier 2011; Lund-Thomsen 2013); but the relationship between these rights as enshrined in transnational labor governance and the existing context for industrial relations at the national and firm levels has not been systematically explored.

This paper thus aims at advancing the conceptual, theoretical, and analytical understanding of the role of labor agency in transnational private governance. More precisely, we ask two interrelated questions. First, how do different types of transnational private regulatory initiatives (such as corporate codes of conduct and multi-stakeholders initiatives), national laws and institutions governing industrial relations, and local firm levels of application interact? Second, how are such interactions likely to support workers' collective capacity to take action to improve their own conditions of employment? The existing literature addressing the relationship between transnational private governance and labor agency remains fragmented. Many studies are primarily descriptive, whereas others tend to privilege the transnational level of lead firms' and multi-stakeholder initiatives' engagement (Gereffi et al. 2005; Neilson et al. 2014; Riisgaard and Hammer 2011a). Although multilevel approaches to transnational governance have brought national settings and local-level phenomena into the picture, surprisingly few studies have examined in any detail the extent to which transnational regulatory initiatives may vary on the ground and even less how this may particularly affect 
workers (notable recent exceptions include: Amengual and Chirot 2016; Anner 2017; Bartley and Egels-Zandén 2016).

This paper is intended to supplement existing scholarship by bringing together global political economy, international relations, business ethics and industrial relations studies in order to focus on the actual workers' capacity to act in, and interact with transnational private regulatory initiatives. This allows us to respond to the following gaps in the literature. First, we aim at more fully linking the transnational, national and local levels in which interactions of labor governance take place. Second, we propose an analytical framework, which we call hybrid production regime, in order to build on recent scholarship's emphasis on labor agency and how such agency is likely to interact between transnational, national and local levels. As such and in contrast with other approaches, we use workers as an entry point. Third, this framework is designed to specify the distinct competence needed for workers' capacity to act at all three levels.

In a sense, our framework of analysis aims at taking the following appeal by Barrientos and her co-authors at its word: "In the end, 'reembedding' global markets will undoubtedly require hybrid and complementary institutions of governance, both public and private, operating at multiple levels - global, national and local" (Barrientos, Gereffi, et al. 2011, p. 313). The framework indeed addresses the conditions under which the increasing number of workers involved in global production networks may reinforce their capacity to act in a way that would translate into improved employment conditions for themselves. We argue that three distinct collective competences combine within a hybrid production regime to enact the relationship between private regulatory initiatives and their context of application regarding labor standards: first, the ability of workers' organizations to gain access to processes of employment regulation, implementation and monitoring; second, their ability to insist on the inclusion of employers and state agencies in charge of industrial relations within such processes; and third, the ability of workers to effectively use their capacity to act as a means of leverage in pursuit of particular goals. In brief, we suggest that workers' capacity to act at the firm level in the way provided for by freedom of association, collective bargaining, and industrial action not only rests on capital-labor relations as such, but also depends on how such collective competences in terms of access, inclusion, and leverage are addressed in the institutionalization of capital-labor relations at the transnational and national levels.

The paper is organized as follows: The fist part presents a thorough and interdisciplinary review of the literature on transnational private governance, corporate social responsibility 
(CSR) and labor agency. The second part outlines the analytical framework of hybrid production regime and further discusses labor agency in transnational labor governance and interactions between transnational, national and local levels. The conclusion wraps up the argument and draws some further implications of our analytical framework.

\section{Transnational private labor governance and agency}

The rise of transnational private governance has highlighted the importance of non-state actors in international relations. Most studies focus on the role of business (Büthe and Mattli 2011; Cutler et al. 1999; Graz and Nölke 2008; Scherer et al. 2016) and non-governmental organizations (Börzel and Risse 2010; Keck and Sikkink 1998; Risse 2002). Until recently the role of workers and unions in transnational private governance has remained largely neglected (Zajak et al. 2017; Brookes 2017; Egels-Zandén and Hyllman 2007). However, labor rights in multinational companies and their supply chains have become significant cross-border issues involving state and non-state actors. In a world where economic, political and social aspects of global production networks are closely interconnected, the existing body of labor rights regulation is under increasing pressure to provide all workers related to supply chains with adequate legal and political protection. It has become particularly difficult to hold multinational companies legally accountable for human rights and labor rights violations in countries where their suppliers are located. The result is a patchwork of regulation for transnational labor governance (Hassel and Helmerich 2016; Hassell 2008).

Three main themes, which contribute to our understanding of transnational labor governance, appear in the literature: first, how private regulatory initiatives and multi-stakeholder arrangements span multi-level operations from the transnational to the national and local level of production; second, an emphasis on national and local contexts of labor governance; third, the role of labor agency at all three levels. This literature review aims at showing that in order to study transnational private governance and sustainable standards, particularly in the field of labor, different levels of analysis - transnational, national, and firm level - must be properly combined and balanced in such a way as to give due account to the agency of labor.

\section{Private regulatory initiatives and multi-level governance}

A number of scholars have studied how distinct institutional designs and membership affect transnational private governance in various policy domains. The implementation of transnational labor standards thus depends on how private regulatory initiatives are designed, which issue areas they cover, and which actors they include as full or associate members of 
the arrangement. The design also influences whether or not an initiative is perceived as legitimate (Fransen 2012a; Koremenos et al. 2001; Levi-Faur 2011; Mitchell 2009). Multistakeholder initiatives involving state representatives, civil society and business actors were initially thought to be more accountable and legitimate than business-driven codes of conduct (Beisheim and Dingwerth 2008; Dingwerth 2007). In that vein, a deeper reliance on what Lund-Thomsen and colleagues (2016) name "local cluster governance" is likely to improve the local institutionalization of corporate social responsibility (CSR) by providing local trade bodies such as business associations and chambers of commerce with the means to implement CSR commitments.

Moreover, Anner has shown that the degree of obligation of private regulatory initiatives such as the Fair Labor Association depends on the particular stakeholder involvement and issue areas under examination: "corporate-influenced programs will be more likely to emphasize monitoring minimal labor standards (minimum wages, hours of work, health and safety) to increase their legitimacy, but will be less likely to emphasize the monitoring and remediation of FoA [freedom of association] rights since these rights are perceived to lessen managerial control [over their supply chain] (Anner 2012a, p. 612).

We build on this literature to consider that it is not only important to analyze which issue areas are strengthened or omitted, but also the extent to which workers in transnational supply chains benefit from transnational labor regulation. In this regard, Fransen (2012a, 2012b) has made a significant contribution to the understanding of institutional designs and stakeholder involvement by providing evidence of ways in which business-driven initiatives change their institutional design to appear as if they were multi-stakeholder initiatives supposedly more likely to benefit workers. For instance, businesses engage with external stakeholders but do not allow them to have a vote or a voice within the initiative when it comes to actual decisionmaking. In addition to excluding certain actors, the vast majority of these initiatives also do not include union representatives or workers. This shows the little legitimacy that businesses grant trade unions and is consequently one of the rationales of the general mistrust of the labor movement towards CSR (Brammer et al. 2012; Harvey et al. 2017).

Moreover, private regulatory initiatives tend to focus on narrow sets of issues in local implementation projects in the factories and fields of developing countries (Barrientos and Smith 2006). Such findings lead us to explore how to better connect the analysis of the institutional design of private regulatory initiatives at the transnational level to national contexts and local-level developments at firm level. We suggest that the interactions of 
transnational private regulatory initiatives with national and local contexts help us understand the dynamics of transnational labor standards at the firm level.

Various strands of scholarship have developed frameworks of analysis to bind the different levels of transnational private governance more tightly. A large body of literature on CSR and public-private partnerships in developing countries in the areas of health, environment and social issues has explored how the transnational and local levels may interact. Beisheim and Liese $(2014 ; 2013)$ view this interaction as a top-down process of implementation of transnational standards at the local level with an emphasis on problem solving. They posit that public-private partnerships are more likely to be successful if there is a win-win situation for the actors who are involved in the partnership. However, this only includes interests of transnational-level actors. As Riissgaard and Hammer (2011b, p. 2) point out, this is an "attempt to implement and enforce labour standards via the power of lead MNCs, creditors, or international organizations in supplier and subcontractor companies along the supply chain". In our view, such a problem-solving and top-down approach runs the risk of depoliticizing a highly political and contested issue - labor rights.

The business literature on CSR has recently started to turn away from such a bird's view in win-win or business case approaches. For example, the evolving paradox perspective on corporate sustainability "explicitly acknowledges tensions among different desirable, yet interdependent and, at times, conflicting sustainability objectives such as environmental protection and social well-being" (Hahn et al. 2018, p. 235). This is the gap that Bartley and Eglels-Zandén (2016) address between CSR engagements and local-level working conditions. In their view, the pressure to reduce that gap lies either directly within the board of the transnational private initiative or, on the contrary, in the immediate institutional environment of the firm expected to conform to the CSR engagements, "from actors at the point of implementation" (Bartley and Egels-Zandén 2016, p. 235). This argues for taking localized forms of institutionalism seriously.

In a similar vein, the institutional literature on corporate social irresponsibility highlights the fact that reputational concerns do not lead necessarily to corporate social responsibility. Jackson and colleagues find that there is an "absence of an aggregate reputational penalty for irresponsibility" and suggest that it is important to turn to studying "how stakeholders respond to irresponsible actions, and how societies seek to regulate these activities" (Jackson et al. 2014, pp. 158, 155). On that note, peer control might force corporations to abide by their obligations. This echoes what Baumann-Pauly and al. (2017) propose with their cultural 
business ethics approach so as to include all participants relevant to the institutional platform in assessing the legitimacy of CSR measures from multi-stakeholders initiatives. And more broadly, what Scherer and colleagues (2016) have in mind when calling for a political CSR 2.0 with a greater role for governments and international organizations.

By and large there is a burgeoning debate in CSR and transnational private governance scholarship that is moving towards recognizing tension, struggles and conflicts of interests. It falls short, however, of fully including issues such as power, inequality, and protest movements. As Bartley (2007) emphasizes from a critical institutionalist standpoint, the transnational private regulation of labor and environment should also be viewed as a result of political conflicts. He calls this a "political construction of market institutions," where institutions such as transnational private certification emerge as an outcome of political contestation of a wide array of state and non-state actors involved as institutional entrepreneurs. Likewise, the institutional approach put forward by Brammer and colleagues emphasizes that CSR should be understood as a mode of governance far beyond the voluntary behavior of corporations and rather looks like a "contested institution" (2012, p. 12). Embedded in historical and political developments, CSR and other instruments of transnational private governance thus reflect an institutionalized form of social solidarity. Far from a choice between voluntary and mandatory regulatory approaches, distinct forms of CSR may exist is the various ways of constructing business-society relations (Brammer et al. 2012).

Besides adding to the literature on tensions and political contestation in transnational private governance, we also aim at developing a theoretical approach that brings the different levels of labor governance together more systematically: the transnational, national and local. Recent scholarship on transnational business governance interactions focuses on the "heterogeneous actors that possess varying regulatory capacities, act within diverse institutional contexts, and seek both to influence the exercise of regulatory authority and to perform regulatory tasks throughout the policy cycle" (Eberlein et al. 2014, p. 3; see also Rasche 2012; Wood et al. 2015). Transnational business governance does not operate in isolation, but rather among many different schemes interacting with one another and with the state. Transnational business governance is thus viewed as "a dynamic, co-regulatory, and coevolutionary process involving state, nonstate, and hybrid actors and organizations that pursue varied interests, possess different regulatory capacities, and interact at multiple levels and in multiple ways, with a range of effects" (Eberlein et al. 2014, p. 14). 
This approach focuses on the many interactions among the wide range of existing transnational private regulatory schemes and does an excellent job in mapping different drivers, mechanisms, pathways and actor constellations within a comprehensive typology. But it falls short in theorizing about how drivers of such interactions can be identified, how they stand in relation to one another, how they relate to all of the various mechanisms and pathways, how these mechanisms and pathways, in turn, relate to one another, and ultimately how actors relate to all of the aforementioned categories. In addition, studies in transnational business governance interactions mostly focus on the transnational level and tends to neglect the theorizing of the national and local levels of labor governance.

An emerging strand of scholarship has focused on the concept of translation to provide an alternative understanding of the links that constitute the multilevel aspect to transnational governance (Berger 2017; Berger and Esguerra 2017). In this perspective, multilevel governance is neither a top-down nor a bottom-up process, but rather a continuous go back and forth between the transnational, national, and firm levels. Transnational labor standards thus create political contestation at all three levels. A distinct focus on the concept of translation (loosely borrowed from the hermeneutic of Walter Benjamin and Paul Ricoeur) can shed some light on the ability of actors to transform the meaning of norms as defined by private regulatory initiatives and to reinscribe them in the actors' own sociopolitical context. As Berger (2017, p. 3) points out, this is "an unavoidably political task" which requires an intimate knowledge of the context, resources and some room for maneuver. The translation literature reminds us that transnational standards are often contested, and that actors struggle over norms' interpretation and their transformation at the national and local levels. It shows us something about the power relations between actors embedded in feedback loops of multilevel governance. As it mostly relies on ethnographic methodology, it tends, however, to privilege the local context and thus falls short of fully conceiving the links between local actors and the national and transnational planes of norms aspiring to be global.

The importance of national and local contexts

Ultimately, transnational private labor governance is here to make a difference, that is, being able to address some of the challenges that global production networks pose for workers directly or indirectly enrolled into them. Many studies focused on the country level or the firm level in emerging economies or developing countries analyze implementation, compliance, and monitoring issues of transnational standards (Kim 2013; Oka 2010; O'Rourke 2003; Oseland et al. 2012). Some of them have examined in detail local firm-level characteristics 
and drivers, which have improved compliance with labor standards at the supplier level (Alexander 2018; Barrientos et al. 2016; Yu 2008). These studies yield three important findings.

First, some studies have emphasized the limited impact and conditions of audits and monitoring on compliance with labor standards at the supplier level. Compliance with labor standards is likely to increase if monitoring is combined with a remediation process in which the brand name company is involved (Oka 2016, p. 665). Moreover, depending on how the auditing processes are designed, auditors may discover infringements of some parts of company codes of conduct more easily than of others. For example, auditors can more easily detect issues related to workplace health and occupational safety standards than to discrimination or sexual harassment (Barrientos and Smith, 2006). The majority of the research rests on the national or firm level, and such studies usually lack theorizing as regards multilevel mechanisms and drivers of transnational labor governance.

Second, while the vertical dimension of the governance mechanisms of the global production networks is clearly instrumental, compliance with private regulatory initiatives is more likely to be successful when coupled with the horizontal dimension in which the work and employment context of suppliers lie. For instance, findings of Locke and colleagues (2007) on Nike's code of conduct show that compliance is more likely when coupled with work organization and human resources practices that give workers more autonomy and power at the factory floor. The same might be true for some types of organization of production such as lean production, which has a positive effect on compliance with labor standards, especially on factory wage levels and working hours, but less so on health and safety (Distelhorst et al. 2017; Locke and Romis 2010). Moreover, training workers in skills for lean production tends to empower them as management is more prone to be treating them well, wary of losing their skilled workforce(Locke et al. 2007, p. 33). At the same time, other studies remind us that suppliers investing in the costs of better training may not be rewarded and run the risk that buyers subsequently shift elsewhere to other less expensive suppliers (Locke et al. 2009, pp. $328-9)$.

Third, some studies use the concept of layering of rules to analyze the relationship between transnational regulation and state regulation as potential complementarities or as conflicts between different forms of labor regulation (Bartley 2011; Locke et al. 2013; Wood et al. 2015). The more empirically driven strand of this literature finds that, under specific conditions, private standards can strengthen the implementation of governmental labor 
regulation. Scholars posit, for example, that private regulation can be complementary to state regulation in developing countries and emerging economies and in this sense depends on the importance of the shadow of strong public regulation (Amengual 2010; Berliner and Prakash 2014; Coslovsky and Locke 2013). Distelhorst and colleagues (2017) have furthermore shown that the likelihood of remediation is higher when state regulation can punitively fine suppliers shown by audits of private regulatory initiatives to have violated labor rights than in cases involving weaker state regulatory contexts. In addition, they stress the importance of civil society organizations in compliance procedures in contexts marked by weaker government institutions. In contrast, Bartley (2018, p. 33) has highlighted possible perverse effects of strong democratic domestic governance structures, which can impede compliance by making it too costly. For their part, Amengual and Chirot (2016) bring the factory level back into consideration. They point out that workers can mobilize against the state to demand compliance with labor standards; this only works under the condition that transnational regulators support worker mobilization from below. Although not all in agreement, these studies show that national and firm-level contexts play an important role in furthering compliance with transnational labor standards. We build on this literature in that we include aspects of national institutional contexts and industrial relations aspects into our theoretical approach.

\section{The return of labor agency}

The third element of transnational private labor governance we discuss here is labor agency. A number of studies from distinct disciplinary backgrounds have recently attempted to bring labor agency to the fore, not only in management and business ethics (e.g. Lund-Thomsen 2013; Niforou 2015), but also in human and economic geography and social anthropology (Carswell and De Neve 2013; Coe and Hess 2013), or development studies and international political economy (Alford et al. 2017; Brookes 2017; Egels-Zandén and Merk 2014; Ben Selwyn 2013). Here, we are interested in two sets of important dimensions: first, the role of workers as agents within the structure of governance at the transnational and national levels; second, how this structure interacts with the capacity of workers to act at the firm level, and how this entails aspects of industrial relations.

Regarding the role of workers within the structure of transnational private labor governance, a shared understanding of recent scholarship is to focus on labor agency to better explain compliance with transnational labor standards and variety in the enforcement of different standards at factory level. In one of the few studies linking labor agency with transnational 
labor governance, Bartley and Egels-Zandén (2016, p. 241) rely on a quantitative analysis of 120 Indonesian firms in the textile and apparel sector and find a positive correlation between the presence of a code of conduct in transnational companies and collective bargaining agreements at firm level. In one of the few large-N studies drawing on compliance data for the ILO's Better Factories Cambodia program, Oka also examines the influence of labor on compliance with transnational labor standards (Oka 2016). She finds a decrease in violations of labor standards, "especially with regard to wage, hours and leave," when a union is present at the workplace, except in cases of multiple unions at the workplace, that "allows management to 'divide and rule' by playing one union against another' (Oka 2016, p. 665). In addition, Helmerich (forthcoming) shows that labor agency in transnational labor governance is also driven by sector-based institutionalization of multi-country alliances.

In short, these studies focus more on the role of workers in strengthening compliance with transnational standards than on how workers can empower themselves at the factory level (an exception is the recent study on the Accord on Fire and Building Safety in Bangladesh showing how unions have enacted a variety of power resources to bolster the implementation of the Accord (Zajak 2017). In bringing the role of workers back into the discussion, we are not solely interested in how labor activism at the firm level can support compliance with transnational labor standards. We also look at how labor agency may be a significant aspect in labor governance at the local, national and transnational levels.

This review has aimed at addressing three gaps in the literature on transnational private governance and labor standards. First, we showed the need to rebalance studies of transnational business governance away from value chains and the mere transnational level of interactions on which logics of competition, coordination, and conflict take place. This means properly linking the multiple levels of labor governance - transnational, national and firmlevel - in order to explain institutional and agential interactions. Second, we draw from the literature that private regulatory initiatives on corporate social responsibility and labor standards cannot do away with workers' own capacity to act, regardless of the importance of the interactions with rules set within transnational arenas and the national legal order of labor laws and institutions governing industrial relations. This presumes bringing workers back in the center of the broader socio-spatial organization of global production networks entwining the local, national and transnational levels. Third, while an emerging literature recognizes the importance of labor agency, scholars tend to focus on union activism at the local supplier site; here, our contribution is to develop an analytical framework that theorizes the agency of key 
actors in transnational labor governance and which especially includes the role of workers at all three levels.

\section{Theorizing global hybrid production regimes}

Transnational private regulatory initiatives bind multinational corporations to labor standards. Multinational corporations in turn expect suppliers worldwide to comply with those standards. Such initiatives and actors are all part of a broader environment that we call a hybrid production regime. The concept describes a configuration of institutions, policies, and practices that involve state and non-state actors in the organization of global production networks. Thus defined, the concept is clearly broader in scope than any single private regulatory initiative, be it a code of conduct such as those used by large multinational corporations or a multi-stakeholder initiative bringing onboard civil society and public organizations, trade unions, and any further actors, such as in the Ethical Trading Initiative (ETI) or the Fair Labor Association (FLA). At the same time, its scope is not as broad as to embrace the whole institutional framework designed to respond to the instability and crisisprone characteristics of capitalism, as for instance the so-called accumulation regime conceived by French regulation scholars to describe the comprehensive compatibility between production, income distribution and demand. This indeed supposes a much broader 'set of regularities that ensure the general and relatively coherent evolution of capital accumulation [in general]' (Boyer 2002) in (Labrousse and Michel 2017, p. 1). Hybrid production regimes rather belong to what Levi-Faur (2011, p. 5) calls the "hybrid architecture of regulatory capitalism" where state and non-state actors coevolve in interactions of different types and statutes. In his analysis, this leads to twenty-seven different forms of regulatory design that combine regulators, regulatees and third parties. While this helps shed light on recent changes in the politics of regulation, the hybrid attribute is mostly used to denote the complexity that derives from the involvement of new actors in the regulatory design of capitalism, whether market-based or not-for-profit civil society organizations.

A growing body of research in international relations, organization and business studies and cognate fields has drawn on the notion of hybrid to emphasize the non-conventional characteristics of such new forms of power and regulation (Bair 2017; Djelic and Quack 2010; Hurt and Lipschutz 2015; Weiss 2014). The notion of hybridity is often used as a default attribute to describe what rules on a transnational scale are not, for instance neither public nor private, or neither just domestic, nor mostly transnational. This leaves us short of 
fully understanding their underlying logic. Drawing on the argument developed by Graz (2019) to theorize the power of standards in the worldwide extension of the service economy, the purpose of using the concept of hybridity here is to acknowledge that far from just a default attribute, it refers to an ontological ambiguity at the core of what confers power on such rules. Such ambiguity describes the category of agents likely to be in a position to set rules, as well as those involved in their monitoring or expected to comply with them. Ambiguity also characterizes the interaction of the different levels where these rules play out. It follows that the territorial space of national sovereignty will intertwine with the transnational space in which contractual obligations linked to the governance of a supply chain are carried out. Likewise, local actors may combine tools set by private regulatory initiatives for use at the transnational level of their governance structure with action taken at the national level of civil courts.

The production regime is thus hybrid insofar as it rests on the ambiguity of relations between institutions, policies and practices, which provides leeway to a wide range of actors for organizing global production networks. Ambiguity may become a strategic resource in the hands of the most powerful actors as well as a potential lever of contestation in the hands of actors deprived of such resources. This echoes recent shifts in CSR scholarship that lays more emphasis on the politicized social framework and governance structure in which appraising the behavior of companies (Brammer et al. 2012; Levy and Kaplan 2009). As Levy and Palpacuer (2017, pp. 337-342) point out, global production networks are "contested political and economic arenas ...; [they] connect global economic regimes with local nodes of activity, and struggles over value appropriation reverberate across the spatial terrain". Hybrid production regimes thus belong to a broader policy project supporting the involvement of new actors across borders to get to grips with power relations closely or loosely related to the globalization of production networks. As the definition presented above clearly shows, such configuration of institutions, policies and practices in the organization of global production networks has not replaced the state, which retains a central role in the rise of transnational private labor governance. In the same way as studies on labor standards stress the importance of the shadow of strong public regulation (Amengual 2010; Coslovsky and Locke 2013), a wide range of issues analyzed in international political economy shows the complementary and subsidiary role of non-state actors in regard to state functions (Cutler et al. 1999; Graz and Nölke 2008). As Payne and Philips (2014, p. 475) point out, "most complex governance arenas inevitably require that both types of [public and private] actor are comprehensively 
engaged if progress towards solutions to policy dilemmas is to be achieved". At the same time, the ambiguous status of non-state actors entails that, in contrast to complementary function, they can also challenge the state with struggles, for instance, to overcome passive or active resistance to effective compliance with labor rights. As Strange (1996, p. 94) suggested long ago in her pioneer study the Retreat of the State, "between the two extremes of non-state authorities welcomed and opposed by states lie certain non-state authorities whose relation to governments is variable or ambiguous".

In the next section, we develop the theorizing of hybrid production regimes and its ability to support workers' capacity to act in order to improve their employment relations in global production networks. It starts with a discussion on how this approach helps rebalance the three levels (transnational, national, local) studied in various ways in the literature on transnational private labor governance. It then attempts to provide insights on how the approach is in the wake of studies that bring labor agency to the fore and what this implies in terms of power. Finally, we consider how to operationalize the power of labor agency by distinguishing more concrete competences, on which workers must rely to be able to act in hybrid production regimes.

\section{$\underline{\text { Rebalancing levels of analysis }}$}

Hybrid production regimes stretch over three levels: the transnational, the national and the local level of the suppliers' firm and its close environment. Distinct, and sometimes overlapping, configurations of institutions, policies, and practices are likely to support workers' agency at the transnational, national and local levels. At the transnational level, corporate codes of conduct, private regulatory initiatives, standards and rights set by, for example, the ILO core labor standards, the OECD Guidelines for Multinational Enterprises, the investment conditionality scheme operated by the International Finance Corporation, or Bangladesh Accord on Fire and Building Safety all contribute to shaping such a regime. At the national level, this mainly involves formal labor market and industrial relations institutions, vocational training programs, and practices. This not only concerns the alignment of provisions of transnational private initiatives with national legal frameworks and labor institutions. It includes how state agencies at different levels of its administration (for instance, regional and local state authorities) are important in the continuing negotiations surrounding the implementation of specific requirements set by transnational private initiatives. Labor inspectors are for instance sometimes powerless to act when they notice 
infringements to labor laws, as the bureaucratic system in which labor inspections are organized may be dysfunctional, slow and subject to bribery ${ }^{\text {ii }}$.

Ultimately, such a regime also includes provisions specifically targeting concrete working conditions at the local level of the firm and its close environment - be it a manufacturing company, a farm producing commodities for exports or a service firm active in offshoring business processes. For example, Social Accountability International's (SAI) code includes "freedom of association and the right to collective bargaining", established at the transnational level with reference to, and sometimes-ambiguous interpretations of, ILO Convention 98. If the SAI freedom-of-association and right-to-collective-bargaining code is implemented by companies, say, in Brazil in the cocoa production industry, then it interacts with Brazilian national labor law and industrial relations institutions and the local firm context of cocoa production in, say, the State of Bahia.

To what extent, then, does this approach help rebalance the transnational, national and local levels of analysis in the study of labor agency in the governance of global production networks with a renewed emphasis on the capacity of workers to act collectively at the firm level? For the sake of clarity, it is important to distinguish between labor rights included in transnational labor regulation and national labor market institutions, on the one hand, and workers' capacity to act at the local (firm) level on the other. While transnational and national levels of the regime are likely to shape labor agency - this is what labor standards schemes are all about - the reverse is also true. Workers' struggles through collective action seek not only to improve their own working conditions locally. These struggles also target progressive change in national labor laws and force transnational initiatives to respond to the social forces that are likely to ultimately shape them. Such labor agency is by and large mediated by trade unions. But at the local level, they can include less organized forms of action based on workers' awareness of their disruptive capacity in the functioning of global production networks, in particular at some of its most strategic "choke points" (Quan 2008).

Our review of literature already discussed empirical studies on various enabling factors supporting the role of workers and unions in transnational private governance. Selwyn points out that a bottom-up approach to labor standards, which takes workers' capacity to act into account, should not treat the institutionalization of capital-labor relations embedded in private regulatory initiatives and national settings "as analytically prior to those relations themselves" (Benjamin Selwyn 2015, p. 112). It follows, then, that hybrid production regimes are not just defined by institutional characteristics at distinct levels, but also by power relations 
determining who produces what, which share of added value to distribute and how such allocation should be made. This prompts us to discuss further the question of power of labor agency.

\section{$\underline{\text { Labor agency and power }}$}

Hybrid production regimes shape the connection between transnational labor standards and the local context of employment relations in which they operate. Paraphrasing Bartley (2018, pp. 45-6), far from filling empty spaces of weak middle- and low-income states, hybrid production regimes are implemented in the "crowded space" of domestic governance, including an array of actors, agendas, and rules shaped by power relations and defining the relationship between the economy, society and polity. Such emphasis on a comprehensive and sociologically informed understanding of the power of transnational private governance to convey substantive rules echoes a pioneer project on labor, power and world orders launched long ago by Robert W. Cox and Jeffrey Harrod when they were in command of the International Institute for Labour Studies at the ILO (Cox and Harrod 1972). This ultimately prompted Harrod to call for "joining the two IRs" - industrial relations and international relations - and thereby “connecting workplace to world order" (Harrod 1997, p. 112).

How shall we account for such power and agency likely to get the most out of ambiguous configurations shaping hybrid production regimes? By including elements of transnational governance and industrial relations, hybrid production regimes reflect several dimensions of power. Core aspects of structural power undoubtedly characterize them, in their ability to shape significant structures of the world economy and the rules that channel the potential for changing them. As Barnet and Duval (2005, p. 53) point out, structural power allocates differential capacities to actors depending of their position and shape their self-understanding interests. While this includes the asymmetry of capital-labor relation in contemporary global capitalism, the position that workers have in the production process also gives them structural power. A case in point is what we referred above as strategic "choke point" of global production networks subject to disruptive actions from workers. More importantly, the relation between transnational private regulatory initiatives and workers' capacity to act at the local level rests on associational power, which Wright describes as 'the various forms of power that result from the formation of collective organization of workers (Wright 2000, p. 962) quoted in (Benjamin Selwyn 2015, p. 102). Following Selwyn, we assume that such capacity to act and ultimately improve their employment relations results from "workers' ability to transform their structural power into associational power" (Benjamin Selwyn 2015, 
p. 108; see also Coe and Hess 2013, p. 5). In other words, neither the position of workers in the production process, nor the rights included in the labor standards provisions of private regulatory initiatives are enough to make up for the potential hardship of employment in global production networks. Workers need use such position and rights to organize and obtain concessions from management. In doing so, they generally follow strategies devised by unions. This being said - and on a more general basis -, such dispositional characteristics of the power of hybrid production regimes cannot be confined to a pre-defined resource, be it structural or associational. It arises from broad social relations that extend beyond the organizational forms taken by industrial action. As Guzzini $(2009$, p. 7) argues with regards to the concept of power, "the distribution of resources says little independent of the specific conditions which apply to the social relations at hand. Power is relation- and situationspecific".

Hybrid production regimes thus define all-embracing terms and conditions of the employment relationship. They result from a play of power varying according to the presence, absence and interaction of different groups of actors within a particular regulatory arena (Hancher and Moran 1998). The outputs of the processes within the regime add up to employee welfarethat is, the actual material rewards of work, and the concrete, measurable aspects of the physical and relational context in which the wage-labor nexus occurs. This includes both outcome standards and industrial relations process rights. While outcome standards are set for specific minimum employee welfare conditions, process rights provide for ways in which workers and all other relevant state and non-state actors can act in such a way as to shape these conditionsiii. The existing literature shows that private regulation has led to some improvement in outcome standards but only very limited impact on process rights (Anner 2012b; Bartley 2018; Egels-Zandén and Merk 2014; Lund-Thomsen and Lindgreen 2014; O'Rourke 2003). Yet process rights such as freedom of association and collective bargaining rights are significantly more important in the long run as they empower workers and trade unions to take action on their own behalf in pursuit of durable improvements of their employment relations. This is why the International Labour Organization describes them as "enabling rights [that] make it possible to promote and realize decent conditions at work" (ILO 2008, p. 5). In brief, labor agency depends on such enabling rights to act, which in turn must be translated into concrete competences for workers to shape hybrid production regimes in their own way. This is what we will focus on now. 


\section{Collective competences}

Workers' capacity to act in a hybrid production regimes depends on a series of collective competences: who is permitted, but also who is required to participate in the regulatory arena, what "rules of the game" apply to participants. By and large, those rules uphold three competences that we call: access, inclusion, and leverage. Figure 1 illustrates this analytical framework.

\section{[Insert Figure 1 approximately here]}

The first competence defines the access of workers, their representatives and state agencies responsible for such policies to the regime, in particular: to be entitled to be recognized by employers as representing the interests of workers in the process of setting outcome standards; to act collectively pursuing employees' common interests; to negotiate (collective) agreements; to monitor remediation; and to voice complaints in case of labor conflicts. The Bangladesh Accord, negotiated in the wake of the collapse of the Rana Plaza building in 2013 with a death toll of more than 1'100 workers, provides a good case in point for illustrating the significance of access as a core collective competence supporting workers' capacity to act in hybrid production regimes. The Accord aimed at improving health and safety standards in the textiles industry and garment production in Bangladesh from 2013-2018 and covered two million workers in Bangladesh. It was signed in 2013 by seven Bangladeshi trade unions, two international trade union federations, IndustriALL and UNI Global Union, and 180 apparel corporations under the coordination of the ILO (Bangladesh Accord 2013; Scheper 2017, p. 2; Zajak 2017). Not only buyers must ensure that their suppliers are fully in compliance with the text's requirements, they cannot shift orders to unmonitored suppliers. By inviting workers to voice their problems within the steering committee, the Accord successfully granted local unions and international trade federations access to the regime where they could participate in negotiations of the agreement, pursue their common interests collectively and agree on implementation monitoring and remediation. This shows the ability of actors to achieve a high degree of access in a hybrid production regime at the transnational level.

The second collective competence secures the inclusion of employers and state agencies in the regime, i.e., the circumstances under which workers are entitled to demand that employers and state agencies participate in existing institutional processes involving the establishment and review of labor standards, and in which workers are already recognized as legitimate participants. This includes all measures taken to ensure that collective bargaining agreements 
are, as far as possible, made available to all employers and to all groups of workers ${ }^{\text {iv }}$. Here we can bring up the case of the Performance Standards of the International Finance Corporation (IFC) - the loan conditionality scheme implemented by the largest provider of capital to the private sector in development countries. The initiative praised as a benchmark for the private sector in developing countries (Warner 2006) provides in reality few guarantees regarding actual workers' competence in terms of inclusion. The guiding documents available are silent on the circumstances under which it is reasonable for a business to recognize a union and what constitutes reasonable employer behavior in reaction to approaches from existing trade unions wishing to organize their workplaces (Cradden and Graz 2016). If we take the test case of the Bujagali Hydropower Project on the Victoria Nile in Uganda that union chose to test the robustness of the standards, some degree of inclusion existed at the onset of the project, though. The IFC investment officer in charge was instrumental in facilitating the inclusion of the local union in the negotiation process of the collective agreement with the client and contractor. He also coordinated contact at the national level by involving the Ugandan Labour Ministry. However, once the initial part of the project was achieved and the IFC officer retracted, the lack of a continuous transnational pressure was detrimental to the inclusion of employers and state agency to the regime when the time came for negotiations of collective bargaining (Cradden and Graz 2016). This shows the fragility of such apparatus when private regulatory initiatives are not ensuring a lasting implication at the local level as well as the dynamics of inclusion and exclusion of national and local actors whose scope for maneuver eventually depends on the involvement of transnational stakeholders.

The third collective competence concerns leverage, that is, the kind of industrial and political pressure that can be mobilized legitimately through different types of organization, whether in order to press a claim for access to the regime, to insist upon the inclusion and participation of other organizations and State agencies, or in pursuit of the establishment of specific outcomes. Recent complaints under the aegis of the OECD Guidelines for Multinational Enterprises illustrate how leverage can take place. The Guidelines are non-binding principles committing governments to encourage multinational enterprises to "respect human rights [and] ... address adverse human rights impacts with which they are involved" (OECD 2011, p. 31). OECD national contact points are responsible for providing grievance mechanisms in alleged cases of non-observance. ${ }^{\mathrm{v}}$ There have been several prominent cases involving large German textile discount firms sued for fires in factories of their suppliers in Bangladesh and Pakistan, where hundreds of people were killed (ECCHR 2015; Lukas et al. 2016, pp. 21-59). 
In one of them, surviving workers of a factory fire in Pakistan launched a tort-based business and human rights lawsuit in a German Civil Court. ${ }^{\text {vi }}$ The German firm KiK was eventually deemed not responsible for the fire in a first appeal judgment (ECCHR et al. 2019). However, this example shows the very possibility of leverage for workers by filing complaints and obtaining mediation in the buyer's jurisdiction.

Such an analytical framework aims at unpacking the channels through which actors participate and exercise their rights in hybrid production regimes. These channels hinge upon the three workers' collective competences defined as access, inclusion, and leverage. While these competences add up to the power resources available to workers, we assume that the potential for using them depends on a wide range of factors and certainly not solely on formal process rights established in private regulatory initiatives. At the transnational level, workers' collective competence nevertheless includes the right to have a voice and to participate in the organizational and supra-organizational processes by which outcome standards are set, monitored, revised, etc. At the national level, the hybrid production regime includes formal labor market and industrial relations institutions, and training and skills enhancement systems. The issues at stake are whether and, if so, how national-level institutions interact with the transnational level, and eventually shape distinct patterns. Such patterns affect the inclusion, access and leverage of actors vis-à-vis the hybrid production regime (see Figure 1).

We theorize that multi-stakeholder initiatives may have an impact on local firm-level industrial relations by introducing new process rights or reinforcing those that already exist. This implies, as a first step, looking at hybrid production regimes and how they provide collective competences for actors to have access, be included and have leverage at the transnational level of private regulatory initiatives and at the national level of labor regulation. It involves examining disjunctures and complementarities between the transnational and the national levels for each of these three competences. The framework thus allows for an elaborate understanding of interactions between the transnational and national levels of the hybrid production regime. It should help to better distinguish patterns of most prevailing interactions. In a second step, this framework allows for explaining how this then affects workers' capacity to act at the firm level.

Each component of a hybrid production regime can be analyzed in terms of the degree to which it supports workers' collective competence of access, inclusion and leverage. For example, a particular hybrid production regime may be characterized by a high degree of support for trade union access to a multi-stakeholder initiative at the transnational level and 
by a moderate degree at the national level of labor market and industrial relations institutions; furthermore, it may provide no support for inclusion of employers and state or interstate agencies in a multi-stakeholder initiative at the transnational level, and only a moderate support at the national level; finally, it may include no support for trade union leverage in a multi-stakeholder initiative at the transnational level, and no support at the national level.

Such an analytical framework aims at rebalancing multilevel approaches of transnational governance and studies on transnational business governance interactions beyond the mere transnational plane of the value chain. Moreover, it provides specific analytical tools for the argument made by recent studies that corporate social responsibility and labor standards ultimately depend on workers' own capacity to act in complex socio-spatial organizations. Above all, the transnational and national levels of the regime may combine institutions, rights and standards in more or less complementary or clashing ways.

\section{Conclusion}

This paper offers a analytical framework for studying transnational labor governance, from the transnational level of private regulatory initiatives such as corporate codes of conducts and multi-stakeholder initiatives, to local sourcing sites of suppliers, via national labor institutions and state agencies. We have developed the concept of hybrid production regimes to shed light on the ambiguous configuration of institutions, policies and practices shaping the relations between labor, production, and power in global production networks. We contend that the interactions between transnational, national, and local levels explain to a great extent the likelihood of labor agency in transnational private governance. We argue moreover that such interactions depend on workers' collective competences within the hybrid production regime, defined as access, inclusion and leverage, briefly exemplified through the cases of the Performance Standards of the International Finance Corporation, the OECD Guidelines for Multinational Enterprises, and the Bangladesh Accord.

The paper provides a constructive engagement with the growing body of literature examining the potential benefits of transnational labor governance for unions and agency at the factory level in developing countries and emerging economies. By shifting the focus of enquiry away from transnational private regulatory initiatives to labor agency, it supports criticism of global governance regimes that treat workers as "passive objects of regulation" (Bartley and EgelsZandén 2016; Egels-Zandén and Merk 2014, p. 466). In doing so, it supplements business studies that have begun to move towards institutional approaches and acknowledges the 
ultimate political nature of business engaging in corporate social responsibility. It stresses that such compliance with transnational labor standards depends on patterns of interactions with national and firm levels.

Future studies could build on this approach in the following ways. They could further develop such a multi-actor and multi-level approach to analyze interactions among different levels of the hybrid production regime and empirically probe how this can effectively support labor agency worldwide. This would widen actor-centered perspectives in business studies that largely remain focused on the role of multinational corporations in transnational labor governance. This would also reinforce the detailed understanding of the contested political economy shaping negotiations over rules governing global production networks. This would clearly provide ground for promising research on how nation states and non-state actors from developing countries and emerging countries engage in transnational private governance. We hope that by bringing the literature on business as a political actor one step further, future research on hybrid production regimes will help include specific aspects of agency and power in transnational labor governance and workers' capacity to act at the local level of the firm and its close environment.

\section{References}

Alexander, R. (2018). Sustainability in global production networks - Introducing the notion of extended supplier networks. Competition \& Change, 22(3), 255-273.

Alford, M., Barrientos, S., \& Visser, M. (2017). Multi-scalar Labour Agency in Global Production Networks: Contestation and Crisis in the South African Fruit Sector. Development and Change, 48(4), 721-745.

Amengual, M. (2010). Complementary Labor Regulation: The Uncoordinated Combination of State and Private Regulators in the Dominican Republic. World Development, 38(3), 405-414.

Amengual, M., \& Chirot, L. (2016). Reinforcing the State: Transnational and State Labor Regulation in Indonesia. ILR Review, 69(5), 1056-1080.

Anner, M. (2012a). Corporate Social Responsibility and Freedom of Association Rights: The Precarious Quest for Legitimacy and Control in Global Supply Chains. Politics \& Society, 40(4), 609-644.

Anner, M. (2012b). Corporate Social Responsibility and Freedom of Association Rights: The Precarious Quest for Legitimacy and Control in Global Supply Chains. Politics \& Society, 40(4), 609-644.

Anner, M. (2017). Monitoring Workers' Rights: The Limits of Voluntary Social Compliance Initiatives in Labor Repressive Regimes. Global Policy, 8(S3), 56-65.

Arnold, D., \& Center, C. A. (2011). Wage and Workers' Voice: Labour and Global Production in Cambodia. Presented at the Better Work Research Conference: Workers, Firms, and Government: Understanding labour compliance in global supply chains, Washington D.C. 
Bair, J. (2017). Contextualising compliance: hybrid governance in global value chains. New Political Economy, 22(2), 169-185.

Bakvis, P., \& McCoy, M. (2008). Core labour standards and international organizations. Friedrich-Ebert-Stiftung Briefing Papers, (6). http://library.fes.de/pdffiles/iez/05431.pdf. Accessed 27 September 2017

Bangladesh Accord. (2013). Accord on Fire and Building Safety in Bangladesh. http://bangladeshaccord.org/wp-content/uploads/2013/10/the_accord.pdf. Accessed 7 September 2017

Barnett, M., \& Duvall, R. (2005). Power in International Politics. International Organization, 59(Winter), 39-75.

Barrientos, S., Gereffi, G., \& Pickles, J. (2016). New dynamics of upgrading in global value chains: Shifting terrain for suppliers and workers in the global south. Environment and Planning A, 48(7), 1214-1219.

Barrientos, S., Gereffi, G., \& Rossi, A. (2011). Economic and social upgrading in global production networks: A new paradigm for a changing world. International Labour Review, 150(3-4), 319-340.

Barrientos, S., Mayer, F., Pickles, J., \& Posthuma, A. (2011). Decent work in global production networks: Framing the policy debate. International Labour Review, 150(34), 297-317.

Barrientos, S., \& Smith, S. (2006). The ETI code of labour practice: Do workers really benefit? University of Sussex: Institute of Development Studies. Accessed 1 March 2008

Barrientos, S., \& Smith, S. (2007). Do workers benefit from ethical trade? Assessing codes of labour practice in global production systems. Third World Quarterly, 28(4), 713-729.

Bartley, T. (2007). Institutional Emergence in an Era of Globalization: The Rise of Transnational Private Regulation of Labor and Environmental Conditions. American Journal of Sociology, 113(2), 297-351.

Bartley, T. (2011). Transnational Governance as the Layering of Rules: Intersections of Public and Private Standards. Theoretical Inquiries in Law, 12(2), 1.

Bartley, T. (2018). Rules without Rights: Land, Labor, and Private Authority in the Global Economy. Oxford: Oxford University Press.

Bartley, T., \& Egels-Zandén, N. (2016). Beyond decoupling: unions and the leveraging of corporate social responsibility in Indonesia. Socio-Economic Review, 14(2), 231-255.

Baumann-pauly, D., Nolan, J., van Heerden, A., \& Samway, M. (2017). Industry-Specific Multi-Stakeholder Initiatives That Govern Corporate Human Rights Standards: Legitimacy assessments of the Fair Labor Association and the Global Network Initiative. Journal of Business Ethics, 143(4), 771-787.

Beisheim, M., \& Dingwerth, K. (2008). Procedural Legitimacy and Private Transnational Governance: Are the Good Ones Doing Better? SFB-Governance Working Paper Series, June(14).

Beisheim, M., \& Liese, A. (2014). Transnational partnerships: effectively providing for sustainable development? Houndmills: Palgrave Macmillan.

Berger, T. (2017). Global Norms and Local Courts: Translating the Rule of Law in Bangladesh. Oxford: Oxford University Press.

Berger, T., \& Esguerra, A. (Eds.). (2017). World Politics in Translation: Power, Relationality, and Difference in Global Cooperation. Abingdon: Routledge.

Berliner, D., \& Prakash, A. (2014). Public Authority and Private Rules: How Domestic Regulatory Institutions Shape the Adoption of Global Private Regimes. International Studies Quarterly, 58(4), 793-803. 
Börzel, T. A., \& Risse, T. (2010). Governance without a State - Can it Work? Regulation and Governance, 4(2), 1-22.

Boyer, R. (2002). The origins of régulation theory. In R. Boyer \& Y. Saillard (Eds.), Régulation Theory: The State of the Art (pp. 7-20). London: Routledge.

Brammer, S., Jackson, G., \& Matten, D. (2012). Corporate Social Responsibility and institutional theory: new perspectives on private governance. Socio-Economic Review, $10(1), 3-28$.

Brookes, M. (2017). Labour as a Transnational Actor: Alliances, Activism and the Protection of Labour Rights in the Philippines and Pakistan. Development \& Change, 48(5), 922 941.

Büthe, T., \& Mattli, W. (2011). New Global Rulers: The Privatization of Regulation in the World Economy. Princeton: Princeton University Press.

Carswell, G., \& De Neve, G. (2013). Labouring for global markets: Conceptualising labour agency in global production networks. Geoforum, 44, 62-70.

Coe, N. M., \& Hess, M. (2013). Global production networks, labour and development. Geoforum, 44, 4-9.

Coe, N. M., \& Jordhus-Lier, D. C. (2011). Constrained agency? Re-evaluating the geographies of labour. Progress in Human Geography, 35(2), 211-233.

Coslovsky, S. V., \& Locke, R. (2013). Parallel Paths to Enforcement: Private Compliance, Public Regulation, and Labor Standards in the Brazilian Sugar Sector. Politics and Society, 41(4), 497-526.

Cox, R. W., \& Harrod, J. (1972). Future industrial relations: An interim report. Geneva: International Institute for Labour Studies.

Cradden, C., \& Graz, J.-C. (2016). Is Transnational Private Regulation Potentially an Effective Means of Promoting Collective Industrial Relations? Global Labour Journal, 7(1), 3-19. doi:https://doi.org/10.15173/glj.v7i1.2353

Cutler, A. C., Haufler, V., \& Porter, T. (Eds.). (1999). Private authority and international affairs. Albany: SUNY Press.

Dingwerth, K. (2007). The New Transnationalism. Transnational Governance and Democratic Legitimacy. Houndsmills: Palgrave Macmillan.

Distelhorst, G., Hainmueller, J., \& Locke, R. (2017). Does Lean Improve Labor Standards? Management and Social Performance in the Nike Supply Chain. Management Science, 63(3), 707-728.

Djelic, M.-L., \& Quack, S. (2010). Transnational Communities. Cambridge: Cambridge University Press.

Eberlein, B., Abbott, K. W., Black, J., Meidinger, E., \& Wood, S. (2014). Transnational business governance interactions: Conceptualization and framework for analysis. Regulation \& Governance, 8(1), 1-21.

ECCHR. (2015). The OECD procedures regarding surveillance technology against Gamma and Trovicor and regarding working conditions in Asia against KiK, C\&A and Karl Rieker. European Center for Constitutional and Human Rights.

ECCHR, AEFFAA, NTUF, \& Medico International. (2019, January 10). German court dismisses lawsuit against KiK over liability for fire at factory in Pakistan in 2012. Business and Human Rights Resourcse Centre. Dortmund. https://www.businesshumanrights.org/en/german-court-dismisses-lawsuit-against-kik-over-liability-for-fireat-factory-in-pakistan-in-2012. Accessed 14 January 2019

Egels-Zandén, N., \& Hyllman, P. (2007). Evaluating Strategies for Negotiating Workers' Rights in Transnational Corporations: The Effects of Codes of Conduct and Global Agreements on Workplace Democracy. Journal of Business Ethics, 76(2), 207-223. 
Egels-Zandén, N., \& Merk, J. (2014). Private Regulation and Trade Union Rights: Why Codes of Conduct Have Limited Impact on Trade Union Rights. Journal of Business Ethics, 123(3), 461-473.

Fransen, L. (2012a). Multi-stakeholder governance and voluntary programme interactions: legitimation politics in the institutional design of Corporate Social Responsibility. Socio-Economic Review, 10(1), 163-192.

Fransen, L. (2012b). Corporate Social Responsibility and global labor standards. London: Routledge.

Fransen, L. (2013). Global Companies and the Private Regulation of Global Labor Standards. In J. Mikler (Ed.), The Handbook of Global Companies (pp. 437-455). Chichester: Wiley-Blackwell.

Gereffi, G., Humphrey, J., \& Sturgeon, T. (2005). The Governance of Global Value Chains. Review of International Political Economy, 12(1), 78-104.

Graz, J.-C. (2019 forthcoming). The power of standards: Hybrid authority and the globalisation of services. Cambridge: Cambridge University Press.

Graz, J.-C., \& Nölke, A. (Eds.). (2008). Transnational private governance and its limits. London: Routledge.

Guzzini, S. (2009). On the measure of power and the power of measure in International Relations (DIIS Working Paper No. 28). Copenhagen: Danish Institute for International Studies (DIIS).

Hahn, T., Figge, F., Pinkse, J., \& Preuss, L. (2018). A Paradox Perspective on Corporate Sustainability: Descriptive, Instrumental, and Normative Aspects. Journal of Business Ethics, 148(2), 235-248.

Hancher, L., \& Moran, M. (1998). Organizing Regulatory Space. In R. Baldwin, C. Scott, \& C. Hood (Eds.), A Reader on Regulation (pp. 148-171). Oxford: Oxford University Press.

Harrod, J. (1997). Social forces and international political economy: joining the two IRs. In S. Gill \& J. H. Mittelman (Eds.), Innovation and transformation in International Studies (pp. 105-117). Cambridge: Cambridge University Press.

Harvey, G., Hodder, A., \& Brammer, S. (2017). Trade union participation in CSR deliberation: an evaluation. Industrial Relations Journal, 48(1), 42-55.

Hassel, A., \& Helmerich, N. (2016). Institutional change in transnational labour governance: implementing social standards in public procurement and export credit guarantees. In Y. Dahan, H. Lerner, \& F. Milman-Sivan (Eds.), Global Justice and International Labour Rights (pp. 239-265). Cambridge: Cambridge University Press.

Hassell, A. (2008). The Evolution of a Global Labor Governance Regime. Governance, 21(2), 231-251.

Helmerich, N. (forthcoming). A Three-Way Relationship: Multinationals, Local Suppliers, and Labor. In M. Hofferberth (Ed.), Corporate Actors in Global Governance: Business as Usual or New Deal? Lynne Rienner Publishers.

Hurt, S., \& Lipschutz, R. (Eds.). (2015). Hybrid Rule and State Formation. Public-Private Power in the 21st Century. London: Routledge.

ILO. (2008). Freedom of association in practice: Lessons learned. International Labour Office.

Jackson, G., Brammer, S., Karpoff, J. M., Lange, D., Zavyalova, A., Harrington, B., et al. (2014). Grey areas: irresponsible corporations and reputational dynamics. SocioEconomic Review, 12(1),

Keck, M. E., \& Sikkink, K. (1998). Activists beyond borders advocacy networks in international politics. Ithaca, NY: Cornell Univ. Press. 
Keuskamp, D., Mackenzie, C. R. M., Ziersch, A. M., \& Baum, F. E. (2013). Deliberately Casual? Workers' Agency, Health, and Nonstandard Employment Relations in Australia: Journal of Occupational and Environmental Medicine, 55(6), 620-627.

Kim, J. Y. (2013). The Politics of Code Enforcement and Implementation in Vietnam's Apparel and Footwear Factories. World Development, 45, 286-295.

Koremenos, B., Lipson, C., \& Snidal, D. (2001). The Rational Design of International Institutions. International Organization, 55, 761-799.

Labrousse, A., \& Michel, S. (2017). Accumulation regimes. In T.-H. Jo, L. Chester, \& C. D'Ippoliti (Eds.), The Routledge Handbook of Heterodox Economics Theorizing, Analyzing, and Transforming Capitalism. London: Routledge.

Lee, S., \& McCann, D. (Eds.). (2011). Regulating for Decent Work: New Directions in Labour Market Regulation. International Labor Office.

Levi-Faur, D. (2011). Regulation and regulatory governance. In D. Levi-Faur (Ed.), Handbook on the politics of regulation (pp. 3-21). Cheltenham: Elgar.

Levy, D. L., \& Kaplan, R. (2009). Corporate Social Responsibility and Theories of Global Governance. In A. Crane, D. Matten, A. McWilliams, J. Moon, \& D. S. Siegel (Eds.), The Oxford Handbook of Corporate Social Responsibility. Oxford: Oxford University Press.

Levy, D. L., \& Palpacuer, F. (2017). Global Production Networks and the Changing Corporation. In G. Baars \& A. Spicer (Eds.), The corporation: a critical, multidisciplinary handbook (pp. 336-345). Cambridge: Cambridge University Press.

Liese, A., \& Beisheim, M. (2013). Transnational Public-Private Partnerships and the Provision of Collective Goods in Developing Countries. In T. Risse (Ed.), Governance without a State? Policies and Politics in Areas of Limited Statehood (pp. 115-143). New York: Columbia University Press.

Locke, R., Amengual, M., \& Mangla, A. (2009). Virtue out of Necessity? Compliance, Commitment, and the Improvement of Labor Conditions in Global Supply Chains. Politics \& Society, 37(3), 319.

Locke, R., Fei, Q., \& Brause, A. (2007). Does Monitoring Improve Labor Standards?: Lessons from Nike. Industrial \& Labor Relations Review, 61(1), 3-31.

Locke, R., Rissing, B., \& Pal, T. (2013). Complements or Substitutes? Private Codes, State Regulation and the Enforcement of Labour Standards in Global Supply Chains. British Journal of Industrial Relations, 51(3), 519-552.

Locke, R., \& Romis, M. (2010). The Promise and Perils of Private Voluntary Regulation: Labor Standards and Work Organization in Two Mexican Garment Factories. Review of International Political Economy, 17(1), 45-74.

Lukas, K., Linder, B., Kutrzeba, A., \& Sprenger, C. (2016). Corporate accountability: the role and impact of non-judicial grievance mechanisms. Cheltenham: Elgar.

Lund-Thomsen, P. (2013). Labor agency in the football manufacturing industry of Sialkot, Pakistan. Geoforum, 44, 71-81.

Lund-Thomsen, P., \& Lindgreen, A. (2014). Corporate Social Responsibility in Global Value Chains: Where Are We Now and Where Are We Going? Journal of Business Ethics, 123(1), 11-22.

Lund-Thomsen, P., Lindgreen, A., \& Vanhamme, J. (2016). Industrial Clusters and Corporate Social Responsibility in Developing Countries: What We Know, What We do not Know, and What We Need to Know. Journal of Business Ethics, 133(1), 9-24.

Mitchell, R. B. (2009). The Influence of International Institutions: Institutional Design, Compliance, Effectiveness, and Endogeneity. In H. V. Milner \& A. Moravcsik (Eds.), Power, Interdependence, and Nonstate Actors in World Politics. Princeton, N.J: Princeton University Press. 
Morrison, C., Sachetto, D., \& Cretu, O. (2013). International Migration and Labour Turnover: Workers' Agency in the Construction Sector of Russia and Italy. Studies of Transition States and Societies, 5(2), 7-20.

Neilson, J., Pritchard, B., \& Yeung, H. W. (2014). Global value chains and global production networks in the changing international political economy: An introduction. Review of International Political Economy, 21(1), 1-8. doi:10.1080/09692290.2013.873369

Niforou, C. (2015). Labour Leverage in Global Value Chains: The Role of Interdependencies and Multi-level Dynamics. Journal of Business Ethics, 130(2), 301-311.

O'Brien, R. (2013). Labour shapes the global political economy. In R. Palan (Ed.), Global Political Economy, Contemporary theories (2nd Edition.). Routledge.

OECD. (2011). OECD Guidelines for Multinational Enterprises. OECD Publishing.

Oka, C. (2010). Accounting for the Gaps in Labour Standard Compliance: The Role of Reputation-Conscious Buyers in the Cambodian Garment Industry. European Journal of Development Research, 22(1), 59-78.

Oka, C. (2016). Improving Working Conditions in Garment Supply Chains: The Role of Unions in Cambodia. British Journal of Industrial Relations, 54(3), 647-672.

O'Rourke, D. (2003). Outsourcing Regulation: Analyzing Nongovernmental Systems of Labor Standards and Monitoring. Policy Studies Journal, 31(1), 1-29.

Oseland, S. E., Haarstad, H., \& Fløysand, A. (2012). Labor agency and the importance of the national scale: Emergent aquaculture unionism in Chile. Political Geography, 31(2), 94-103.

Payne, A., \& Phillips, N. (Eds.). (2014). Handbook Of The International Political Economy Of Governance. Aldershot: E.Elgar.

Quan, K. (2008). Use of Global Value Chains by Labor Organizers. Competition \& Change, 12(1), 89-104.

Rasche, A. (2012). Global Policies and Local Practice: Loose and Tight Couplings in Multistakeholder Initiatives. Business Ethics Quarterly, 22, 679-708.

Riisgaard, L., \& Hammer, N. (2011a). Prospects for Labour in Global Value Chains: Labour Standards in the Cut Flower and Banana Industries. British Journal of Industrial Relations, 49(1), 168-190.

Riisgaard, L., \& Hammer, N. (2011b). Prospects for Labour in Global Value Chains: Labour Standards in the Cut Flower and Banana Industries. British Journal of Industrial Relations, 49(1), 168-190.

Riisgaard, L., \& Okinda, O. (2018). Changing labour power on smallholder tea farms in Kenya. Competition \& Change, 22(1), 41-62.

Risse, T. (2002). Transnational actors and world politics. In Walter Carlsnaes, T. Risse, \& B. Simmons (Eds.), Handbook of International Relations (pp. 255-274). London: Sage.

Robinson, P. K. (2010). Do Voluntary Labour Initiatives Make a Difference for the Conditions of Workers in Global Supply Chains. The Journal of Industrial Relations, 52(5), 561-573.

Rodgers, G., Lee, E., Swepston, L., \& van Daele, J. (2009). The International Labour Organization and the Quest for Social Justice, 1919-2009. Ithaca and Geneva: Cornell Unviversity Press and ILO.

Scheper, C. (2017). Labour Networks under Supply Chain Capitalism: The Politics of the Bangladesh Accord. Development \& Change, 48(5), 1069-1088.

Scherer, A. G., Rasche, A., Palazzo, G., \& Spicer, A. (2016). Managing for Political Corporate Social Responsibility: New Challenges and Directions for PCSR 2.0. Journal of Management Studies, 53(3), 273-298. doi:10.1111/joms.12203

Selwyn, Ben. (2013). Social Upgrading and Labour in Global Production Networks: A Critique and an Alternative Conception. Competition \& Change, 17(1), 75-90. 
Selwyn, Benjamin. (2015). The grapes of wrath: social upgrading and class struggles in global value chains. In K. van der Pijl (Ed.), Handbook of the International Political Economy of Production (pp. 98-114). Aldershot: E. Elgar.

Strange, S. (1996). The Retreat of the state: the diffusion of power in the world economy. New York: Cambridge University Press.

Thomale, C., \& Hübner, L. (2017). Zivilgerichtliche Durchsetzung völkerrechtlicher Unternehmensverantwortung. JuristenZeitung, 72(8), 385-97.

Warner, M. (2006). The New International Benchmark Standard for Environmental and Social Performance of the Private Sector in Developing Countries: Will It Raise or Lower the Bar? ODI Opinions.

Weiss, L. (2014). America Inc.? Innovation and Enterprise in the National Security State. Ithaca: Cornell University Press.

Wells, D. (2009). Local Worker Struggles in the Global South: reconsidering Northern impacts on international labour standards. Third World Quarterly, 30(3), 567-579.

Wesche, P., \& Saage-Maaß, M. (2016). Holding Companies Liable for Human Rights Abuses Related to Foreign Subsidiaries and Suppliers before German Civil Courts: Lessons from Jabir and Others v KiK. Human Rights Law Review, 16(2), 370-85.

Wood, S., Abbott, K. W., Black, J., Eberlein, B., \& Meidinger, E. (2015). The interactive dynamics of transnational business governance: A challenge for transnational legal theory. Transnational Legal Theory, 6(2), 333-369.

Wright, E. O. (2000). Working-Class Power, Capitalist-Class Interests, and Class Compromise. American Journal of Sociology, 105(4), 957-1002.

$\mathrm{Yu}, \mathrm{X}$. (2008). Impacts of Corporate Code of Conduct on Labor Standards: A Case Study of Reebok's Athletic Footwear Supplier Factory in China. Journal of Business Ethics, 81(3), 513-529.

Zajak, S. (2017). International Allies, Institutional Layering and Power in the Making of Labour in Bangladesh. Development \& Change, 48(5), 1007-1030.

Zajak, S., Egels-Zandén Niklas, \& Piper Nicola. (2017). Networks of Labour Activism: Collective Action across Asia and Beyond. An Introduction to the Debate. Development and Change, 48(5), 899-921.

\footnotetext{
'Both "Workers' agency"(Arnold and Center 2011; Hassell 2008; Helmerich forthcoming; Keuskamp et al. 2013; Morrison et al. 2013) and "labor agency" (Lund-Thomsen 2013; Oseland et al. 2012; Riisgaard and Okinda 2018) are used in the literature. We choose the concept of "labor agency" to depict the collective capacity of workers to act, as their action is only relevant in a collective understanding.

ii Observation made in field work undertaken by one of the co-authors in Bahia, Brazil in May 2018.

iii Outcome standards include rules that specify pay, holiday entitlement, benefits in kind, the provision of safety equipment and so on; the category of process rights encompasses rules that provide workers with rights to have a voice and to participate in the organizational and supra-organizational processes by which outcome standards are set and compliance with them is reviewed.

iv As provided for by the ILO Collective Bargaining Convention No. 154 and its accompanying Recommendation (No. 163) furthering the basic principles set in Convention No. 98.

${ }^{\vee}$ See also OECD Cases handled by the National Contact Points for the OECD Guidelines for Multinational Enterprises, http://mneguidelines.oecd.org/Flyer-OECD-National-Contact-Points.pdf, last accessed September 5, 2017.

${ }^{\mathrm{vi}}$ In the Ali Enterprises garment factory in Karachi, Pakistan, more than 250 persons were killed during a fire in September 2012. The case is called "Muhammad Jabir and others vs. Kik Textilien und Nonfood GmbH" (for more information see: Thomale and Hübner 2017; Wesche and Saage-Maaß 2016).
} 